\title{
The nanomafia: nanotechnology's global network of organized crime
}

\begin{abstract}
The nanotechnology has become a billionaire industry with multiple potential applications on human beings; however, experimentation in humans is high risk, for that reason, the transnational nanotechnology companies would be resorting to criminal methods like the organized crime to achieve that purpose. Thus, mafias of nanotechnology, "nanomafias", would being created, mainly in Latin America, which would be multiplying vertiginously due to several factors like the ignorance in society regarding the use of nanotechnology as criminal weapon, the "invisibility" of this mafia for being used as its tool, the wifi, its economic power, the extortion with the Brain net, the silence and participation of the press and the health unions, the media disinformation campaign, its world interconnection, being an organized crime and the possible participation of authorities of the national police, the prosecutor's office and the judiciary, and the intelligence services. Nanomafia aims to become the greatest organized crime network in the world, therefore, the world society shall know, be alert and report the crimes committed by this nanomafia.
\end{abstract}

Keywords: nanotechnology, internet, interface brain-machine, crime, latin america
Volume 3 Issue 3 - 2018

\author{
David Salinas Flores \\ Faculty of Medicine, Universidad Nacional Mayor de San Marcos, \\ Peru
}

Correspondence: David Salinas Flores, Faculty of Medicine, Universidad Nacional Mayor de San Marcos, Peru, Tel +5I1996371790, Email dsalinas2009@yahoo.com

Received: June 22, 2018 | Published: June 28, 2018

\section{Introduction}

The nanotechnology is the science, engineering and technology that are developed to nano-scale, around 1 to 100 nanometers. One of nanotechnology main applications is the nanobots, machines that can construct and handle objects at an atomic level and that are capable of moving through the circulatory system. ${ }^{1}$

The nanotechnology has become a billionaire industry and since it has multiple potential applications in human beings, there is a great interest in human experimentation. However, the nanotechnology acts at atomic level and for that reason the experimentation in humans is high risk, which causes an evident lack of volunteers. Therefore, the transnational nanotechnology companies would be resorting to criminal methods to get human experimentation subjects; thus, they would be using violence, swindle, extortion and organized crime..$^{-4}$

Recent researches reveal evidences that the technological transnational companies, in illicit association with USA, European Community and China governments and the corrupt Latin American governments, have created an organization that is developing mainly in Latin America a secret, forced and illicit neuroscientific human experimentation with invasive neurotechnology, brain nanobots, microchips and implants to execute neuroscientific projects, ${ }^{2-5}$ which can have even led scientists to win Medicine Nobel Prizes ${ }^{6}$ based on this illicit human experimentation at the expense of Latin Americans' health.

The main potential harmful effects caused by this illicit human experimentation with nanobots in society include:

Mind control, ${ }^{7,8}$ memory deletion, torture, permanent espionage, theft of private information, extortion, sterilization, psychiatric disorders, suicide, and digital slavery. ${ }^{6}$
The mainly objectives of nanomafia are illicit enrichment, academic recognition, creation of human weapons, and the creation of a digital fascist society.

The evidences indicate that nanomafias would be interconnected forming an international network with a mega project whose purpose is to create a digital fascist society, an oligarchy that rules the rest of world citizens who will carry nanobots and will be digital slaves, a human robotisation of the society at the service of a millionaire elite.

The digital fascist project is global; the objective would be to control the whole planet using microchips in human beings, animals and things.

"The Internet of Things" and "the driverless car" really have as purpose the fascist control of things. In men, the "digital slave" (human robot) project has different components: the mind control, permanent espionage with the Brain net, elimination of the emotions, living in a virtual reality, memory deletion and elimination of sexuality.

The different kind of projects developed with nanobots has a common pattern: they are developed by telemetry, by wifi, they do not have physical form, and they are intangible. Really, nanomafia is the mafia of wifi, the "ghost mafia", which makes almost impossible to report it. The torture researchers and the criminals know that "the best torture" is the one that leaves no marks since it cannot be reported. If the victim of tortures by wifi reports it, he/she can be unjustifiably considered as a person with psychiatric problems or a slanderer, for that reason, the crime uses wifi as secret torture weapon (Figures 1) (Figure 2).

Regarding the criminal methods that nanomafia uses, the swindle is one of the most common methods and the main types include the deceptive promotion, the intellectual camouflages or the humanitarian pseudo-aid. 
The deceptive promotion is one of the most popular, it promotes the use of nanobots as a futurist scientific prediction and a benefit to the society, hiding the health risk and its true uses against society; thus, for example, transnational companies scientists state the following regarding the brain nanobots:

\section{"With nanorobots in our brains we will be like Gods"}

"With nanobots we will be able to load the French language in the bloodstream of our brain" 10

However, these affirmations that, evidently, induce the ordinary citizen to use brain nanobots do not have strongest scientific evidence, and the most important is that these affirmations hide the harmful effect of brain nanobots.

In order to convince the citizens of voluntarily accepting being "digital slaves" of the nanomafias, transnational companies, economic powers and media magnates, a series of intellectual camouflages have been created and there is a whole terminology, created or already existing, that is being manipulated to promote the illicit uses of this nanotechnology, a terminology that could be called a "swindle dictionary".

Thus, for promotion of memory deletion is "unlearn to learn"; for convincing of the use of brain nanobots is "the biological innovation" (innovation) $)^{11}$ and thus, with these implants, being "excellent" human beings (excellence), having more creativity ("creativity") a better attitude ("attitude") and being evolved human beings( "evolution") ; for accepting the permanent espionage with the Brain net is "connect", "the privacy is out" "knowledge society", "divergent thinking", "lateral thinking", "observatories", "transparency", "hiving thought", "brainstorming", "disruptive technology, "mindfacture", ${ }^{12}$ "Smart-city", "brain circulation"; for convincing a person of being a cyborg (creative destruction); for forcing the student to use the Brain net as academic tool are currently being developed "neurospecialties" (neurolaw, neuromanagement, neuroeducation, etc.); for living in the virtual reality is "live the experience..... ${ }^{13}$ "; for promoting to live without sexuality is "gender"; ${ }^{14}$ for living in a digital ghetto is "community"; for accepting being a digital slave is the "Milleniums"; 15 and finally for spying the poor (social responsibility); thus, the transnational companies will make the citizens believe that they live in a happy world without knowing that they are digital slaves, slaves not forced by a totalitarian dictatorship but by the mass consent made by the media.

There are several evidences that indicate that the social responsibility is another of the camouflages organized by this nanomafia, due to the strong and sudden interest of the companies in developing "social responsibility" projects with a big-money advertising that indicates that it is a business rather than a humanitarian aid. One of the companies is Fox which is suspected of being using this camouflage. Fox is one of social responsibility promoters, ${ }^{16}$ according to recent researches, that are making TV shows of zombies using mind control experiments with brain nanobots. ${ }^{7}$ The social Responsibility is promoted by prestigious institutions like the United Nations and is recruiting university youth as its main operators swindling them in a majority of cases. The use of transhumanist terminology called the "social innovation" by the social Responsibility organizers and the clichés that promote the personal surveillance as "The eye we all have set begins to see" lead to suspect that the social Responsibility would really seeks to develop the espionage with the Brain net in poor zones. The social responsibility that is demanded as mandatory course in Latin American universities like the Universidad Nacional Mayor de San Marcos, the oldest of South America, would seek to swindle poor populations in order to transform these towns in "communities", really future ghettos of digital slavery, where they will be permanently spied and mentally controlled with the Brain net, their memories will be deleted and their sexual lives will be filmed and commercialized; the residents of these communities will live in a virtual reality. In short, the residents of these poor communities will be human slaves at the service of the transnational companies and nanomafias.

One of the most perverse objectives of this mafia, the mind control, turning a person into an animal, machine or slave, would also be being promoted subliminally through intellectual swindles like the "emotional intelligence", the so-called "intelligent control of emotions", seeking that the society in the future accepts the use of nanobots under the argument of emotions self-control hiding that their mind will not really be auto-controlled but they will lose their control, since the person with nanobots could be controlled and spied through telemetry used by nanomafias or intelligence centrals; their brain and body will actually be under mind control by others.

The actions of this nanotechnology mafia are facilitated because nanobots can be administered in foods and drinks, being one of the main ones the alcohol drinks like beer since it depresses the individual's central nervous system and he loses his self-control and therefore, it facilitates mind control by others via brain nanobots; for this reason, the beer is ideal to administer brain nanobots.

The illicit use of nanotechnology based on secret and forced human experiments would be giving rise to an exclusive corrupt circle of "new millionaires": professors of medicine, health unions, doctors, nurses, technicians, hospital managers, physicists, journalists, publishers of scientific magazines, librarians, engineers, politicians, professors, policemen, prosecutors, judges, the military, university students and even school students who illicitly become rich at the expense of their victims' health and honor.

The illicit nanotechnology has also allowed appearing a new kind of criminals, operators that could be called "nano-hired killers" or "nano-torturers", those responsible for the "dirty work" of nanomafia, group mainly conformed by journalists, university students, nurses and illegal inmigrants as many venezuelans in Peru, who would be responsible for performing several works including: selection of the victim, to choose "the person of interest", person who can contribute with some benefit to the nanomafia; intoxication of the victim with nanobots through food, drinks or pills or his/her kidnapping to install them brain implants; editing, selection and commercialization of mind videos obtained with the daily espionage using the Brain net, mind torture, victim torture disclosing his/her privacy information and espionage of dreams; obtaining information from the dreams with the Brain net for extortion; creation of pseudo-diseases blocking the function of organs by telemetry to then extort the victim with "the cure".

Recent researches alert on the development of nanomafias in Latin America, mainly in Peru. ${ }^{6,4}$ The main suspicious ones include the hospitals of ESSALUD, company that, in 2009, would have started a criminal nanotechnology organization during the administration of Fernando Barrios Ipenza, one of transhumanism sponsors in Peruvian universities in association with European and US universities and the main Peruvian media. ${ }^{6}$ Barrios would continue developing nanomafias in the provinces of Peru, mainly in Huancayo, city where he was mayor. 
These mafias of nanotechnology would be developing dramatically due to the following factors:

i. The ignorance in society regarding the use of nanotechnology as common crime, organized crime, state terrorism and cyberwar weapon.

ii. The "invisibility of this mafia" because they have wifi as their main weapon and therefore is almost impossible to report it.

iii. The economic and political power of this mafia. The main organizers include the transnational companies with more economic power like Google, Facebook and Intel and the governments of countries like China, United States, the European Community and the Russian Federation and especially, the US Army through the DARPA (Figure 3).

iv. The extortion to the victims of nanomafia using new products developed with the nanotechnology like the Brain net. The Brain net allows obtaining the so-called "mind videos", obtaining a person's thoughts in form of videos that can be transmitted to cell phones. Really, the Brain net aims to be the most powerful extortion weapon of the common crime, the organized crime, state terrorism and cyberwar.

v. The silence and participation of the press. Recent publications give evidences that owners of mass media and their extensive network of journalists in the world are the organizers of this mafia of nanotechnology ${ }^{4-7}$ since the main uses of nanobots on humans are projects of telecommunications like the Brain net, a person's permanent espionage by telemetry.

vi. The media disinformation campaign that presents the mind control and the Brain net as a fiction or myth, ${ }^{17}$ thus, the society is informed about nanotechnology as a crime only in science fiction TV series, which leads to consider the crime incredible.

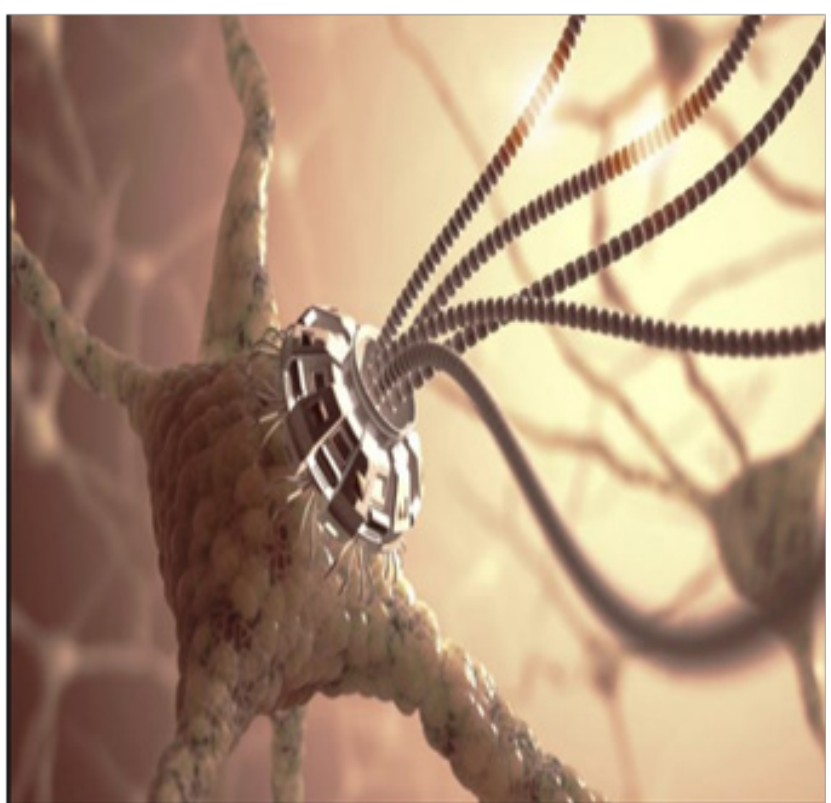

Figure I Brain nanobots: Nanomafia weapon

Source:http://www.huffingtonpost.com/entry/ray-kurzweil-nanobotsbraingodlike_us_560555a0e4b0af3706dbel e2

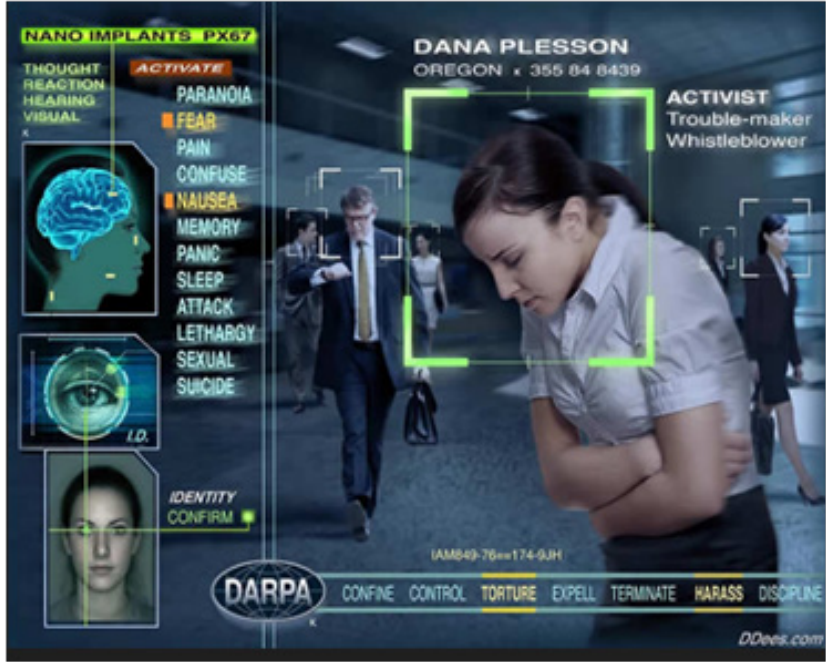

Figure 2 Brain nanobot: Surveillance and mind torture

Brain nanobot can be used to perform a permanent surveillance and torture a person by wifi

Source: https://www.covertharassmentconference.com/

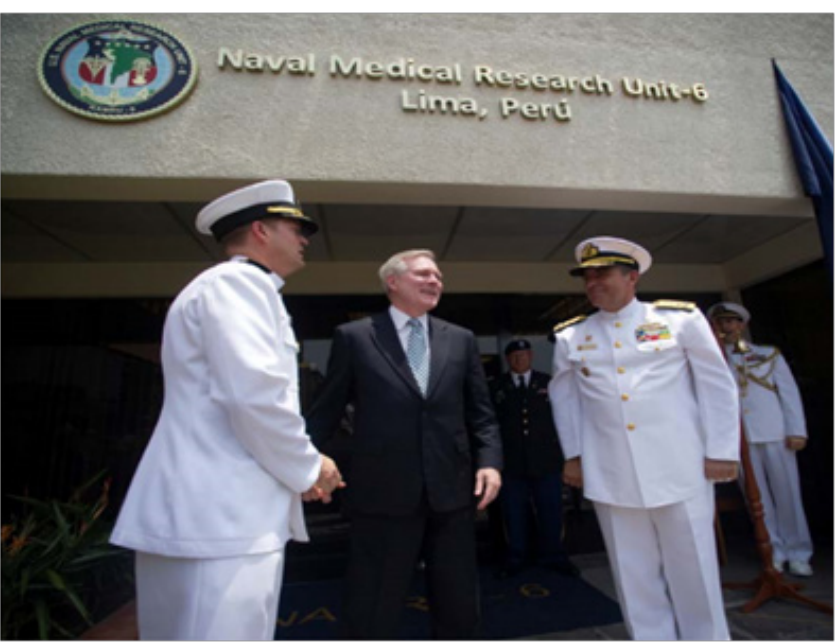

Figure 3 The US Navy: Main suspect of organizing nanomafias in Latin America.

The photo shows Naval Medical Research Unit Six (NAMRU-6), the only US military command located in South America. It is near to Peruvian sea. Recent researches lead to suspect that the US Army is the main organizers of mafias of nanotechnology in Latin America through the DARPA.

Source http://nextnavy.com/welcome-to-you-new-namru-namru-6-grows-up/

\section{The silence and participation of unions}

In Latin America, the health unions participate in multiple street protests, however, it is remarkable their silence in relation to the multiple researches that report forced human experimentation with nanobots in Latin American hospitals, ${ }^{5-7}$ which would reflect their participation in this mafia. In Peru, the Federación Centro Unión de Trabajadores known by its initials "CUT" from the Social Health Insurance (ESSALUD for its initials in Spanish) comprises 18,000 workers. In spite of its large number, which makes it almost impossible 
that their members do not know nanomafias, surprisingly "CUT" an health union has not denounced illicit nanotechnology (Figure 4) (Figure 5).

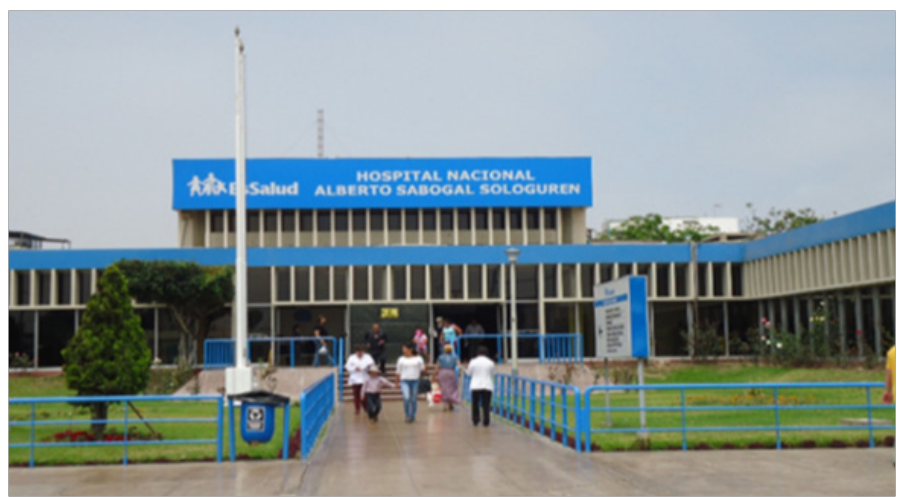

Figure 4 ESSALUD: Peruvian hospital network where nanomafias would operate.

The picture shows the Alberto Sabogal Hospital of ESSALUD. It is near to Naval Medical Research Unit Six (NAMRU-6)

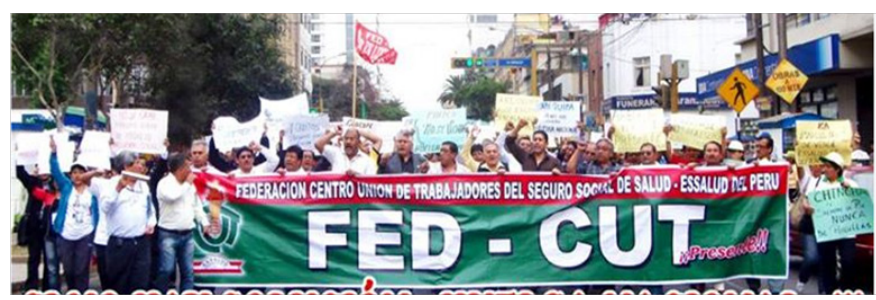

Figure 5 Health unions: Main suspects of organizing nanomafias in Latin America.

The figure shows one of the multiple street protests carried out by one of the Peruvian largest and most powerful health unions known by its initials "CUT". This health union has never protested against nanomafias.

Source: https://www.facebook.com/Fedcutoficial/

The nanomafia aims to be an interconnected worldwide network. One of its main camouflages would be the Millennium project, created, according to its promoters, the United Nations, to develop a "global intelligence", therefore, it forms the "nodes" in different countries; this would actually be to develop the Brain net worldwide.

Alan García, considered one of the most corrupt politicians in Peru, ${ }^{18}$ surprisingly, was the person chosen by the United Nations to develop the Peru Node of the Millennium Project and to advise the RIBER Group, the Latin-American branch of this project. Garcia's corruption fame and his relations with Fernando Barrios lead to suspect that Alan García would be developing the Brain net in all Latin America.

The nanomafia is an organized crime. In contrast to a band in which a group of people meets to commit a single crime, the organized crime organizations are created to commit crimes continuously, at long term; the organized crime is "the crime company", for that reason, to achieve that purpose, one of the main key objectives is to include into it the authorities of the national police, the prosecutor's office and the judiciary, ${ }^{19}$ this makes the success of the criminal organization viable; it explains why the organized crime develops its actions with total impunity and it would explain why the nanomafia, a form of organized crime, has not been reported by any prosecutor's office in the world (Figure 6).

It is also evident that, given the great extension that the nanomafias can have in the world and the large amount of information that institutions like the world intelligence services as CIA or MOSSAD and police institutions like the FBI and the INTERPOL have, these institutions would know the nanomafia but instead of report it they hide it and participate in its crimes. Thus, for example, neither the FBI, the CIA, the MOSSAD or the INTERPOL, or any intelligence service in the world have reported the main nanomafia weapon, the Brain net, and the massive espionage that would be carried out in the world, on the citizens mainly on young women obtaining their sexual life.

It is necessary to emphasize that the criminal activity of this nanomafia, "the ghost mafia", "the wifi mafia", must be known by the society in all areas because it can affect any society sector and for the power of its weapons like the Brain net. The magnitude of this mafia can only be compared to that of drug trafficking. There actually are many similarities between the drug trafficking and this "nanotrafficking" organized by nanomafias, although the main crime element is different, in the former it is the coca leaf and in the latter it is the brain nanobot, both can damage the mental health, both are billionaries industries that infiltrate and corrupt all the institutions, however, unlike the drug trafficking that is reported by mass media in its headlines, in the nanotrafficking the press is its main member and for that reason it hides it, and it remains unknown to most of society that even considers it fiction due to the own press disinformation campaign that presents the crime as fiction.

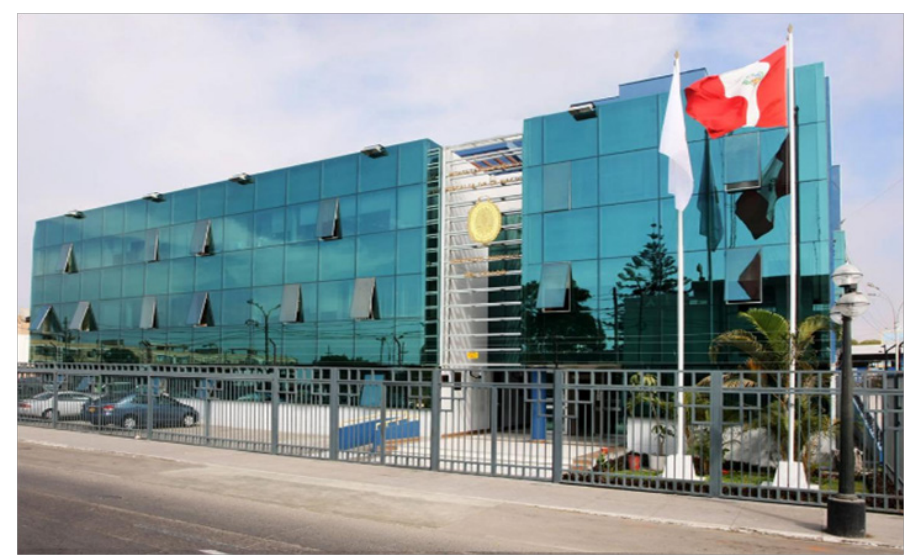

Figure 6 Mafias of Prosecutors: Key element of nanomafias.

The picture shows Callao Prosecutor's Office in Peru; it is near to Alberto Sabogal Hospital, the main place suspected of organizing nanomafia in Peruvian medicine. Until date, no prosecutor's office has made a report about the organized nanotechnology crime in Peru.

Source: https://legis.pe/crean-despachos-plazas-fiscales-callao/

\section{Conclusion}

The nanotechnology has become a billionarie industry with multiple potential applications on human beings, which has leaded to create a mafia of nanotechnology to be developed on human beings. A "nanomafia" that becomes rich with the secret and forced use of nanotechnology on human beings at the expense of their health, privacy and honor. The world society shall know, be alert and report 
the crimes committed by this nanomafia, mafia that aims to become the greatest organized crime network in the world.

\section{Acknowledgements}

None.

\section{Conflict of interest}

Author declares that there is no conflicts of interest.

\section{References}

1. http://singularityhub.com/2016/05/16/nanorobots-where-we-are-todayand-why-their-future-has-amazing-potential/

2. Salinas D. Inteligencia artificial híbrida: Una amenaza a Latinoamérica. Rev Arg Med. 2018;6(1):3-5.

3. Anand R, Matani A. Industrial engineering \& management new delhi india. International Research Publication House. 2015.

4. Salinas D, Alerta Puno. Experimentos humanos ilicitos alto riesgo con empleo de chips y nanobots cerebrales en becarios del PRONABEC. Puno Cultura y Desarrollo. 2016.

5. Salinas D. Proyecto cerebro humano: Existen Experimentos humanos secretos en Latinoamérica?. Arch Med. 2016;16(1):192-8.

6. Salinas D. The "human GPS"- the 2014 Nobel prize in medicine: great scientific fraud?. Int Phys Med Rehab J. 2018;3(3):193-196.

7. Salinas D. El secreto de Hollywood: Zombis creados por nanobots cerebrales. Medicina y Cine. 2018;14(2):87-91.
8. Salinas D. The secret program of US mind control weapons: is it developing in Latin America?. Int Phys Med Rehab J. 2018, 3(2):145146.

9. http://www.huffingtonpost.com/entry/ray-kurzweil-nanobots-braingodlike_us_560555a0e4b0af3706dbe1e2

10. https://bigthink.com/videos/nicholas-negroponte-on-the-future-ofbiotech

11. Salinas D. Innovación: El cuento chino de Andres Oppenheimer Centros. 2016;5(1):1-8.

12. Goñi J Mentefactura. El cambio de modelo productivo. Innovar sobre los intangibles del trabajo y de la empresa. Ediciones Díaz de Santos. 2012

13. http://www.fillima.com.pe/la-22a-feria-internacional-del-libro-de-limanos-convoca-a-vivir-la-experiencia-fil/

14. http://www.ngenespanol.com/fotografia/fotogalerias/17/01/9/edicionespecial-sobre-genero-revista-national-geographic/

15. https://www.lanacion.com.ar/1020257-millennials-la-generacion-delfuturo

16. http://www.dossiernet.com.ar/articulo/fox-international-channels-latinamerica-firma-acuerdo-con-la-ong-unidos-en-red/2271

17. Horgan J. The myth of mind control. Will anyone ever decode the human brain? Discover. 2004:25(10):40-7.

18. https://www.youtube.com/watch?v=3WtQ-6wPKdo

19. https://www.youtube.com/watch?v=2A73zUAQAMM 